\title{
Modern processes of palynomorph deposition at lakes of the northern region of the Rio de Janeiro State, Brazil
}

\author{
CYNTHIA F.P. DA LUZ ${ }^{1,2}$, ORTRUD M. BARTH ${ }^{2,3}$ and CLEVERSON G. SILVA ${ }^{4}$ \\ ${ }^{1}$ Instituto de Botânica, Núcleo de Pesquisa em Palinologia, Caixa Postal 3005, 01061-970 São Paulo, SP, Brasil \\ ${ }^{2}$ Laboratório de Palinologia, Departamento de Geologia, Instituto de Geociências \\ Universidade Federal do Rio de Janeiro, CCMN, J2-19, Ilha do Fundão, 21949-900 Rio de Janeiro, RJ, Brasil \\ ${ }^{3}$ Laboratório de Ultra-estrutura Viral, Departamento de Virologia, Instituto Oswaldo Cruz \\ Fundação Oswaldo Cruz, Avenida Brasil 4365, 21040-900 Rio de Janeiro, RJ, Brasil \\ ${ }^{4}$ Laboratório de Geologia Marinha, Instituto de Geociências, Universidade Federal Fluminense \\ Avenida Litorânea s/n, 24210-340 Niterói, RJ, Brasil \\ Manuscript received on February 12, 2009; accepted for publication on June 17, 2009
}

\begin{abstract}
Palynological analysis of pollen, Pteridophyta spores and algae deposited in the superficial sediments at Lagoa de Cima and Lagoa do Campelo Lakes, located in the north of Rio de Janeiro state, was used to determine the spatial variation of the palynomorphs deposition. A total of 67 pollen types were identified at Lagoa de Cima, with an expressive contribution of regional arboreous taxa, hydrophytes and ruderal plants of the pastureland. The depositional pattern of palynomorphs depends on the fluvial leakage, the proximity of the local sedimentation to the inlet of the Imbé and Urubu Rivers and the bathymetry of lake bottom. The highest concentrations of palynomorphs were observed in the decentralized and less deeper area, without the interference of the northeastern wind. At Lagoa do Campelo, a total of 58 pollen types were identified, among which the majority of the pollen grains came from hydrophytes, with the highest concentrations found along the northeastern shore. The southeastern shore showed high percentages of pollen and spores with degraded exine and mechanical damage, due to the transport through the lake by the currents caused by the wind, confirmed by the depositional trend of damaged palinomorphs along the same direction as the prevailing winds.
\end{abstract}

Key words: algae deposition, Campos dos Goitacazes municipality, palynology, pollen deposition.

\section{INTRODUCTION}

The coastal plain of Campos dos Goytacazes municipality, northern coastal region of the Rio de Janeiro State, is an important area for palaeoenvironmental studies. This region presents several shallow lakes, which are relict bays of a large palaeolagoon system that was isolated from the sea during the Quaternary by sediments from the Paraíba do Sul River (Lagoa de Cima lake), by sand barriers or beach ridges (Lagoa Salgada lake), or by alluvial fans of the Barreiras Formation (Lagoa do Campelo lake) (Martin et al. 1984, 1993, 1997) (Fig. 1).

Correspondence to: Cynthia Fernandes Pinto da Luz E-mail: cyluz@yahoo.com.br
The Lagoa de Cima Lake is embedded in a valley (Imbé River basin) located between the Barreiras Formation and the Crystalline system, $50 \mathrm{~km}$ west from the coastal line and with about $30 \mathrm{~m}$ high. This lake may have been formed by an obstruction of a palaeolagoon called Ururaí Bay, and, therefore, represents the oldest lake in this region. The water is fresh and presents diatomite deposits at its margins. It is conditioned by the inflow of the Urubu and Imbé Rivers and presents an outlet called Ururaí that flows towards the Lagoa Feia Lake, that is connected to the sea by a narrow passage. Nowadays, the Lagoa de Cima Lake drainage basin occupies an area of circa $986 \mathrm{~km}^{2}$ and does not present 

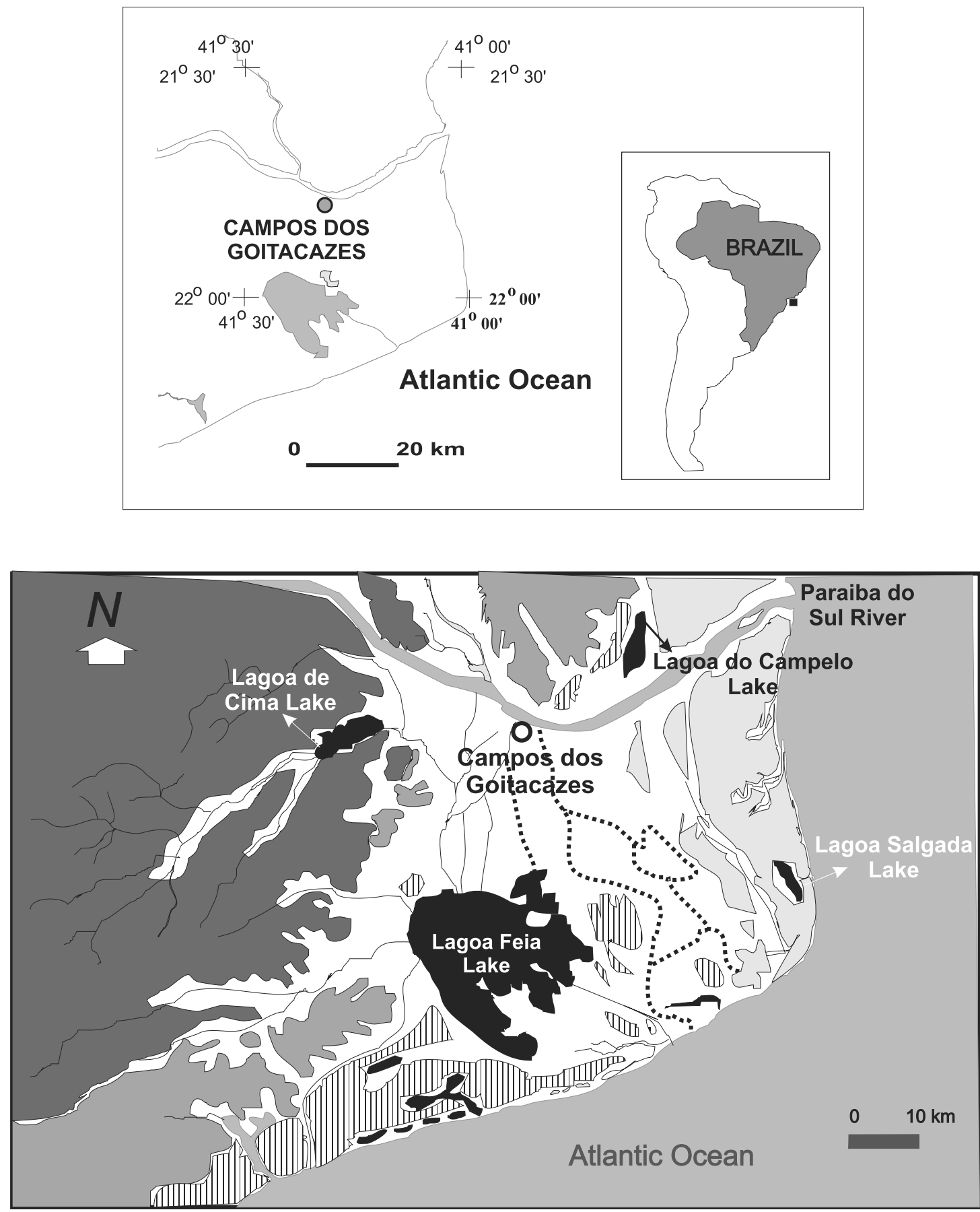

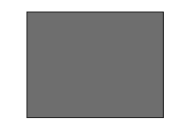

Pre-Cambrian Basement

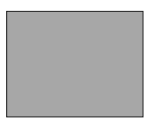

Barreira Formation (Tertiary)

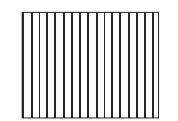

Marine Terrace (Pleistocene)

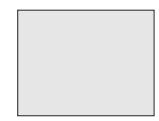

Marine Terrace (Holocene)

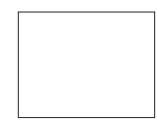

Fluvial and Lagoon deposits (Holocene)

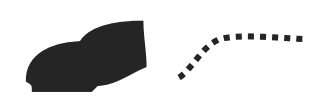

Lakes Paleochannels

Fig. 1 - Geological map of the deltaic plain of the Paraíba do Sul River and location of the Lagoa de Cima and Lagoa do Campelo Lakes, Campos dos Goitacazes municipality (Martin et al. 1993, modified). 
industrial activities but an intense sugar-cane agriculture, pastureland, and a small remnant fragment of the Atlantic forest bordering the lake (Soffiati Netto 1985, 1991, FEEMA 1993). The Evergreen Rainfall forest covers the high mountains of the drainage basin, especially inside the Parque Estadual do Desengano, a governmental area for the protection of the forest that is located $5 \mathrm{~km}$ west from the Lagoa de Cima Lake (RADAMBRASIL PROJETO 1983).

The Lagoa do Campelo Lake is located at $17 \mathrm{~km}$ away from the coastal line, with about $8 \mathrm{~m}$ high, bordering the Barreiras Formation and reaching the flattened sediments of the coastal plain, which cover the Cretaceous layers of the Campos Basin. Its drainage basin is not well limited and occupies an area of circa $98 \mathrm{~km}^{2}$. Without a tributary and an effluent, the lake receives fresh water and sediments from several swamps and bogs connected to the Paraíba do Sul River. The water of the lake was not naturally drained into the Atlantic Ocean (Tolentino et al. 1986). Nevertheless, in 1950 the extinguished National Sanitation Department (DNOS) realize did several drainage alterations in the Campos dos Goitacazes municipality in order to control the natural floods in this region. The building of a channel connecting this lake to the Paraíba do Sul River and another channel towards the sea was not good to its hydrological balance (Soffiati Netto 1985, 1991, Bidegain 2002). A small remnant of the Seasonal Semideciduous forest can be observed at $5 \mathrm{~km}$ southwest of the lake, and a small swampy forest fragment of "Restinga" vegetation in the northeastern margin of the lake. Pastureland, sugar-cane agriculture and subsistence plantations constitute the regional landscape of the drainage basin. The marsh vegetation next to the lake borders presents Cyperaceae, Poaceae, some additional plant taxa, and a characteristic large belt of cattail (Typha).

The Atlantic Forest in this region represents a mosaic of different ecosystems, as xeromorphic beach ridges, "Restinga" vegetation, Tropical Seasonal Semideciduous forest, Evergreen Rainfall forest, hygrophilous/swampy vegetation and grassland. Despite its environmental importance, the economical activities developed in this region since the arrival of Europeans have damaged the original vegetation and the lake/lagoon sediments.
Assumpção and Nascimento (2000) made a floristic analysis of a few forest remnants of the "Restinga" vegetation in Grussaí $(20 \mathrm{~km}$ southeast of the Lagoa do Campelo Lake). The phytosociological structure of a Seasonal Semideciduous forest called "Mata do Carvão", the largest remnant fragment in this region, and located at about $25 \mathrm{~km}$ north of the Lagoa do Campelo Lake, was studied by Silva and Nascimento (2001). Moreno et al. (2003) performed the floristic analysis of the arboreal stratum at $50 \mathrm{~m}$ high in the Imbé Basin. Carauta and Rocha (1988) and Carauta et al. (1992) listed the vegetation composition in this region.

The region has a hot and humid climate with a strong seasonal influence. The rainfall pattern is related to a rainy summer with a dry season from May to September, during the winter, and with indexes above $200 \mathrm{~mm}$ per month (AW of Koeppen). The annual rainfall average is around $900-1,100 \mathrm{~mm}$, and the mean of the annual temperature is around $22^{\circ} \mathrm{C}$. The predominant wind comes from the NE (RADAMBRASIL PROJETO 1983, Tolentino et al. 1986, FEEMA 1993, Bidegain 2002).

With the aim to support the reconstruction of the temporal dynamics of the vegetation during the last 7,000 years, palynological studies of surface sediment samples were performed for elucidation of the current dynamics that have influenced the sedimentation of palynomorphs inside the Lagoa de Cima and Lagoa do Campelo Lakes. In both situations, the anthropic influence was intense and changed almost the whole vegetation cover in the region, which is causing an accelerated lowering of the water level of the two lakes and their eutrophization.

\section{MATERIALS AND METHODS}

Fifteen surface samples were collected with a hand dredger in the top five centimeters of the Lagoa de Cima Lake sediments, in a transect of $500 \mathrm{~m}$ steps from one to the opposite side, in the NE/SW direction, which is the same direction of the dominant wind:

sample 1: $21^{\circ} 45^{\prime} 23^{\prime \prime} \mathrm{S}-41^{\circ} 29^{\prime} 11^{\prime \prime} \mathrm{W}$; sample 2: $21^{\circ} 45^{\prime} 34^{\prime \prime} \mathrm{S}-41^{\circ} 29^{\prime} 35^{\prime \prime} \mathrm{W}$; sample 3: $21^{\circ} 45^{\prime} 42^{\prime \prime} \mathrm{S}-41^{\circ} 29^{\prime} 44^{\prime \prime} \mathrm{W}$; sample 4: $21^{\circ} 45^{\prime} 47^{\prime \prime} \mathrm{S}-41^{\circ} 29^{\prime} 55^{\prime \prime} \mathrm{W}$; sample 5: $21^{\circ} 45^{\prime} 55^{\prime \prime} \mathrm{S}-41^{\circ} 30^{\prime} 11^{\prime \prime} \mathrm{W}$; 
sample 6: $21^{\circ} 46^{\prime} 03^{\prime \prime} \mathrm{S}-41^{\circ} 30^{\prime} 28^{\prime \prime} \mathrm{W}$; sample 7: $21^{\circ} 46^{\prime} 45^{\prime \prime} \mathrm{S}-41^{\circ} 30^{\prime} 42^{\prime \prime} \mathrm{W}$; sample 8: $21^{\circ} 46^{\prime} 19^{\prime \prime} \mathrm{S}-41^{\circ} 30^{\prime} 59^{\prime \prime} \mathrm{W}$; sample 9: $21^{\circ} 46^{\prime} 27^{\prime \prime} \mathrm{S}-41^{\circ} 31^{\prime} 14^{\prime \prime} \mathrm{W}$; sample 10: $21^{\circ} 46^{\prime} 37^{\prime \prime} \mathrm{S}-41^{\circ} 31^{\prime} 28^{\prime \prime} \mathrm{W}$; sample 11: $21^{\circ} 46^{\prime} 45^{\prime \prime} \mathrm{S}-41^{\circ} 31^{\prime} 44^{\prime \prime} \mathrm{W}$; sample 12: $21^{\circ} 46^{\prime} 54^{\prime \prime} \mathrm{S}-41^{\circ} 31^{\prime} 59^{\prime \prime} \mathrm{W}$; sample 13: $21^{\circ} 47^{\prime} 02^{\prime \prime} \mathrm{S}-41^{\circ} 32^{\prime} 12^{\prime \prime} \mathrm{W}$; sample 14: $21^{\circ} 47^{\prime} 11^{\prime \prime} \mathrm{S}-41^{\circ} 32^{\prime} 25^{\prime \prime} \mathrm{W}$; sample 15: $21^{\circ} 47^{\prime} 16^{\prime \prime} \mathrm{S}-41^{\circ} 32^{\prime} 34^{\prime \prime} \mathrm{W}$.

Sample 1 was located about $500 \mathrm{~m}$ shoreline in the NE margin of the lake and related to the $0 \mathrm{~m}$ of the transect line. Samples 6, 7 and 8 were obtained in the deeper portion (circa $3.4 \mathrm{~m}$ deep), near the center of the lake. Sample 15 was collected near a sand bank at the SW margin, between the mouths of the Imbé and Urubu Rivers (Fig. 2).

Four surface samples were collected with a hand dredger in the top five centimeters of the Lagoa do Campelo Lake sediments, in a transect of $500 \mathrm{~m}$ steps from one to the opposite side, in the NE/SW direction, the same direction of the dominant wind:

sample 1: $21^{\circ} 38^{\prime} 25^{\prime \prime} \mathrm{S}-41^{\circ} 10^{\prime} 59^{\prime \prime} \mathrm{W}$; sample 2: $21^{\circ} 38^{\prime} 35^{\prime \prime} \mathrm{S}-41^{\circ} 11^{\prime} 10^{\prime \prime} \mathrm{W}$; sample 3: $21^{\circ} 38^{\prime} 49^{\prime \prime} \mathrm{S}-41^{\circ} 11^{\prime} 22^{\prime \prime} \mathrm{W}$; sample 4: $21^{\circ} 38^{\prime} 52^{\prime \prime} \mathrm{S}-41^{\circ} 11^{\prime} 30^{\prime \prime} \mathrm{W}$.

Sample 1 was located about $10 \mathrm{~m}$ shoreline in the NE margin of the lake and related to the $0 \mathrm{~m}$ of the transect line. This station was about $0.5 \mathrm{~m}$ deep and next to the cattail belt. Sample 2 (1.0 m deep) was collected near the center of the lake. Sample 3 was obtained in the deeper portion of the lake (1.5 m deep), near a sand bank covered with Cyperaceae. Sample 4 (1.0 m deep) was located near the cattail belt in the SW margin of the lake (Fig. 3).

Two grammes of each surface sample were processed using the standard methodology (Ybert et al. 1992). The investigation was established upon the data obtained from palynological analyses of sediments, considering the palynomorphs as pollen grains, spores of Pteridophyta and Bryophyta, zygospores and coenobia of Chloroccocales algae. All palynomorphs present in three microscope slides of each sample were counted and identified at a $500 \times$ magnification, besides the in- troduced Lycopodium clavatum L. spores. Pollen percentages were calculated on the base of the total pollen sum, excluding Bryophyta and Pteridophyta spores, Algae and the pollen grains of hydrophyte plants (Cyperaceae, Eichornia, Nymphaceae, Onagraceae, Sagittaria, Scrophulariaceae, Typhaceae and Utricullaria). The concentration of palynomorphs was plotted considering the number of marker spores per gram of sediment (Stockmarr 1971). The statistical treatment was carried out using TILIA software (Grimm 1987). Pollen grains and spore fotomicrographs with morphological descriptions were presented formerly in Luz and Barth (2000, 2002) and algae in Luz et al. (2002). Palynomorphs were grouped in diagrams according to its habitus (tree, tree/ shrub, shrub, shrub/herb, herb and of variable habitus). No chemical products were used for the observation of Bacillariophyceae algae.

\section{RESULTS}

At Lagoa de Cima Lake a total of 575 pollen grains was counted, 67 pollen types were identified in all surface samples analyzed. Samples 1 and 7 presented no pollen grains. The highest concentration was 80,667 pollen grains/g (sample 3), corresponding to the northeast boundary of the lake, and the lowest (samples 8 , 10 and 12) was found near its center/southwest portion (Fig. 4).

The highest percentage and concentration values of herbaceous pollen types were found in sample $3(46,383$ pollen grains/g), decreasing towards to the southwest margin. Borreria, Cyperaceae, Typhaceae and Poaceae were dominant, while Araceae, Begoniaceae, Cabomba, Dioclea, Eichhornia and Polygonum represented less than $10 \%$.

The dominant arboreal/shrub vegetation pollen types were Cecropia, Celtis, Euphorbiaceae, Melastomataceae, Moraceae, Myrcia, Piper, Trema and several Asteraceae, Fabaceae and Myrtaceae, which presented the highest percentage and concentration values in samples 3, 5 and 11. Alchornea, Arecaceae, Bombax, Casearia, Cedrela, Ceiba, Clethra, Copaifera, Didymopanax, Eryotheca, Eucalyptus, Ficus, Ilex, Meliaceae, Phoradendron, Podocarpus, Rapanea, Rinorea, Sapotaceae, Symplocos, Vochysia and Weinmannia were present in very low percentages, comprising less than $20 \%$. 


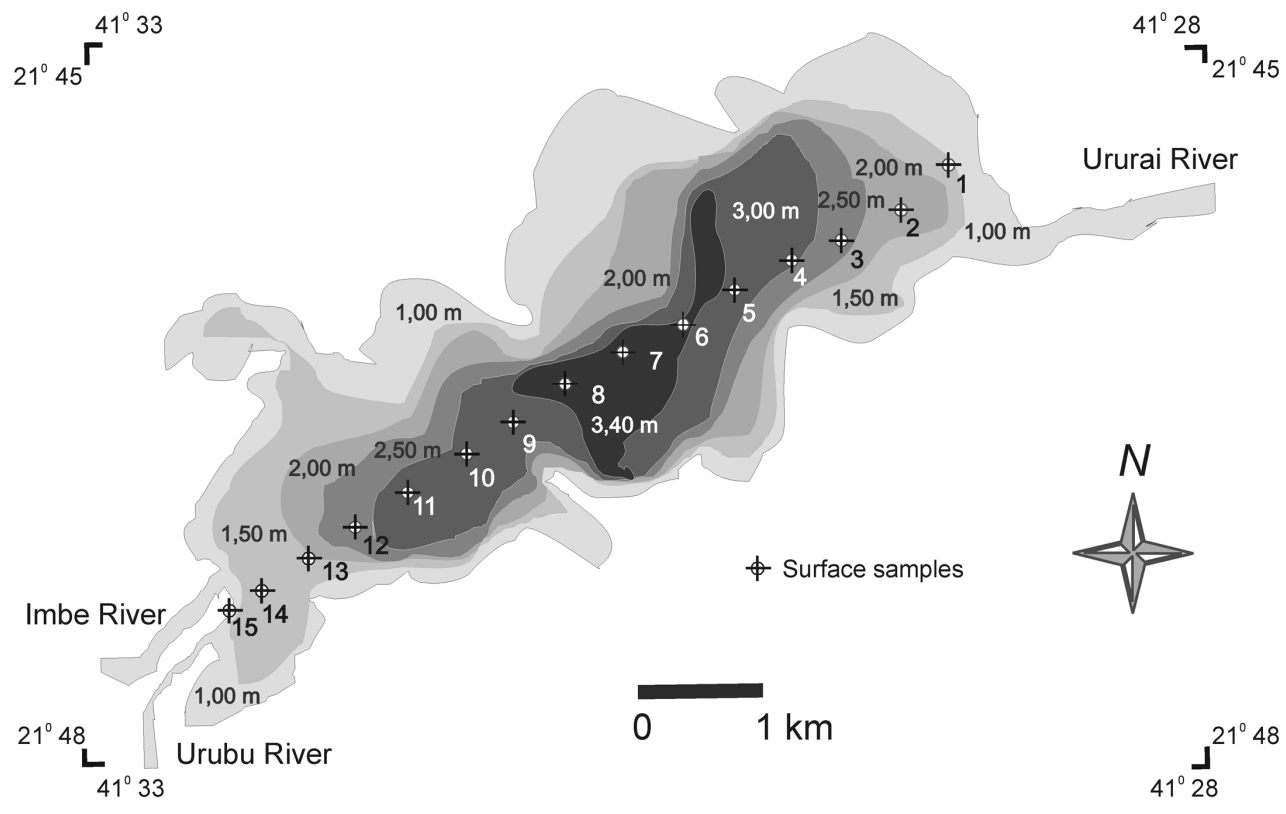

Fig. 2 - Bathymetric map of the Lagoa de Cima Lake with the localization of the surface sediment samples.

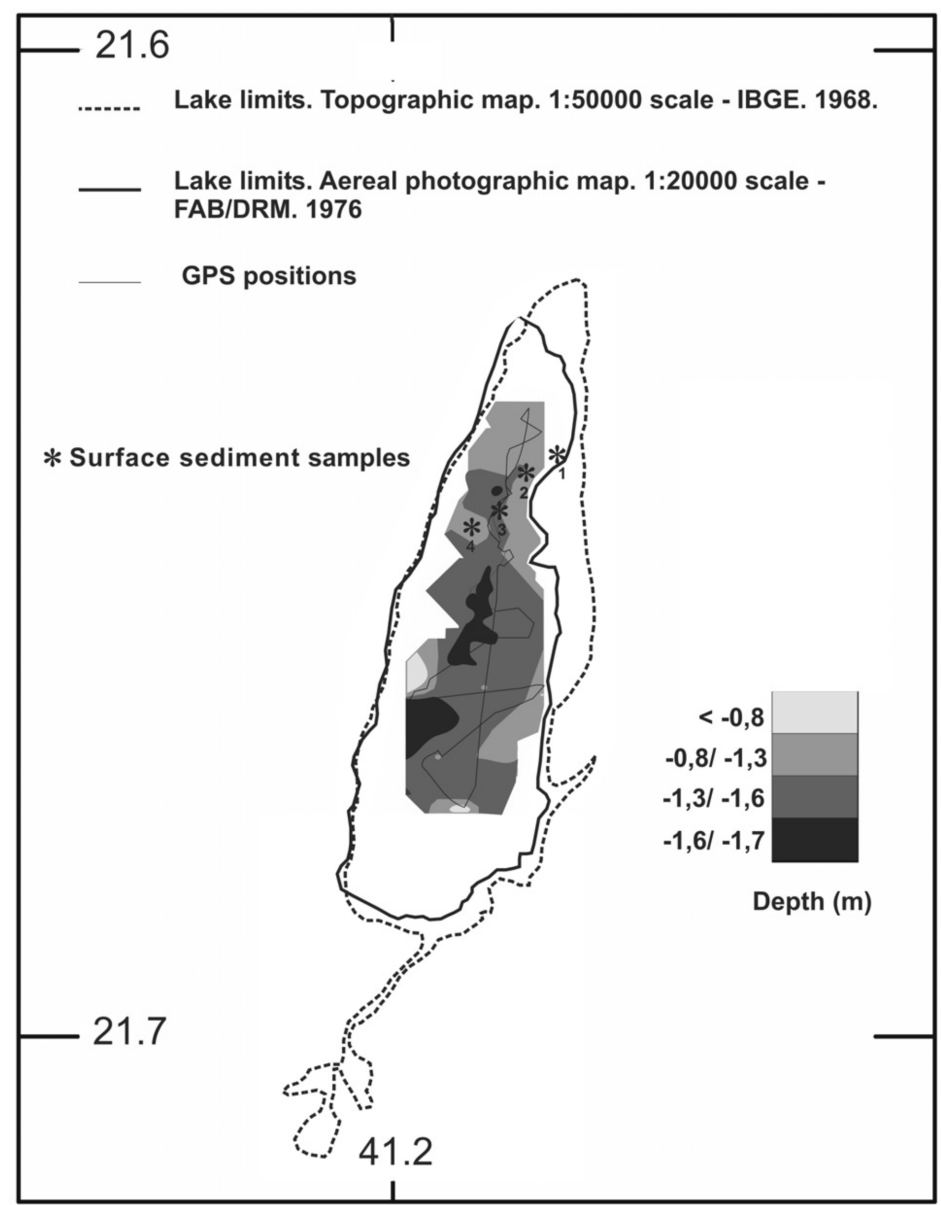

Fig. 3 - Bathymetric map of the Lagoa do Campelo Lake with the localization of the surface sediment samples. 
The fern spores reached a total of 155 spores counted in all samples analyzed, and represented less than $10 \%$ of the total of the palynomorphs. No spores were detected in samples 1 and 7. Its highest percentage and concentration occurred in samples 12,13,14 and 15, in the southwest boundary of the Lagoa de Cima Lake.

Next to the inflows of Imbé and Urubu Rivers, in the southern portion of the lake (samples 15, 14, 13, 12, 11 and 10), high percentages of pollen and spores with degraded and corroded exines were observed.

Algae reached a total of 4,182. Its highest concentration reached circa 800,000 individuals/g in sample 11, and the lowest (less than 1,000 individuals/g) in sample 14. Samples 1, 7 and 15 showed no Chloroccocales. Scenedesmus (S. acunae, S. communis, S. magnus, S. ohauensis, S. pannonicus and S. protuberans) was the dominant genus among the identified algae, followed by Coelastrum (C. proboscideum, C. pulchrum and $C$. reticulatum) and Pediastrum duplex var. subgranulatrum. Mougeotia occurred only in sample 10. Bacillariophyceae were observed in all samples, mainly Aulacoseira granulata, A. granulata var. angustissima, A. italica, Ciclotella meneghiniana, Luticula sp. and Melosira sp.

At Lagoa do Campelo Lake a total of 919 pollen grains were counted, and 57 pollen types were identified in all surface samples analyzed. The highest pollen grains concentration was 212,106 grains/g (sample 1), corresponding to the northeastern boundary of the lake (Fig. 6). Pollen grains concentration decreased towards the southwest margin (sample 4), although showing the highest number of pollen types (36 pollen types).

Pollen grains of the herbaceous vegetation comprised more than $50 \%$ in each sample. Cyperaceae, Typhaceae and Poaceae were the dominant herbaceous pollen types, presenting more than $90 \%$ of all pollen grains (Fig. 5). The highest percentage and pollen grains concentration of cattail (Typha) was obtained in sample 1 (29,182 pollen grains/g), and the highest pollen grains concentration of Cyperaceae was seen in sample 3 (34,071 pollen grains/g). The percentage of Poaceae remained relatively constant (about $35 \%$ in most of the samples), although decreasing to $18 \%$ in the deepest point of the transect (sample 3). Poaceae showed the highest pollen grains concentration in sample $2(26,889$ pollen grains $/ g$ ). Other herbaceous pollen types represented less than 10\% (Alismataceae, Araceae, Borreria, Dioscoreaceae and Polygonum).

Pollen grains of the trees, trees/shrub and shrub vegetation occurred at less than $11 \%$ in each sample (Fig. 5). They showed the highest percentage and concentration in sample 1 and the highest number of pollen types (12 pollen types) in sample 4. Alchornea, Arecaceae, Celtis, Cecropia, Clethra, Lecythidaceae, Myrtaceae, Piper and Trema were the most important arboreal/shrub pollen types. Casearia, Castanea, Cupania, Dorstenia, Gochnatia, Loranthaceae, Meliaceae, Myrcia, Myrsinaceae, Myrsine, Sapindaceae, Sapotaceae, Sloanea, Trichilia, Virola and Weinmannia occurred in very low percentages.

The fern spores reached a total of 159 , representing less than $11.9 \%$ of the palynomorphs in each sample. The highest percentage and concentration occurred in sample 2 (36,300 spores/g).

Most of pollen and spores observed in the surface sediments presented significant exine damages, mainly in samples 3 and 4 .

The highest algae (Chloroccocales) concentration reached 77,582 individuals/g in sample 1, and the lowest $(1,887$ individuals $/ g)$ in sample 4. Pediastrum tetras (Ehrenberg) Ralfs was the dominant species, and its highest percentage occurred in sample 1. Spirogyra and Mougeotia were dominant in sample 4. Mougeotia presented the highest percentages in sample 2 (14\%) and 4 (24\%). Spirogyra did not occurred in sample 1. Bacillariophyceae was not observed.

\section{DISCUSSION}

The extant vegetation and spatial dynamics of the recent deposition of palynomorphs in the surface sediments of the lakes was considered.

The dominant assemblage of pollen types in the Lagoa de Cima Lake agrees with the floristic studies performed by Carauta et al. (1992), Carauta and Rocha (1988) and Rizzini et al. (1997). Nevertheless, the results obtained about the forest composition in the Imbé River basin are partially in agreement with Moreno et al. (2003); they indicated Lauraceae and Fabaceae as the families with a great floristic diversity, followed immediately by Moraceae, Myrtaceae, Sapotaceae, 


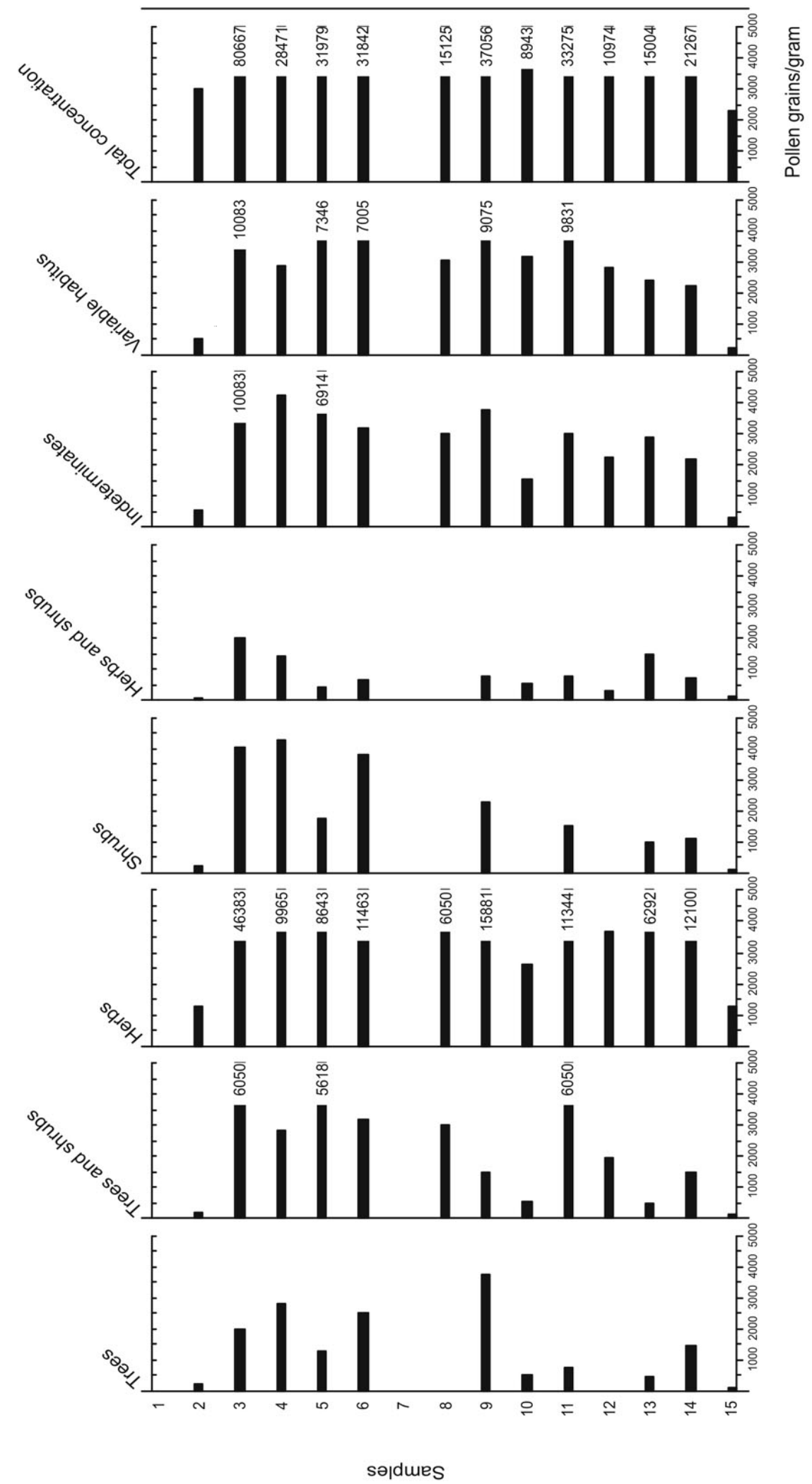

Fig. 4 - Total concentration of pollen grains according to the plant habitus in the surface samples of the Lagoa de Cima Lake. 
Euphorbiaceae and Rubiaceae. Euphorbiaceae had larger canopy values due to the presence of a high number of individuals. Lauraceae pollen grains were not observed in our surface sediment samples, probably because their fragile exine prevents preservation, as well as very few ones of Rubiaceae and Sapotaceae. Pollen grains of Fabaceae, Euphorbiaceae, Moraceae and Myrtaceae were significant. The main pollen source was the vegetation of about $200 \mathrm{~m}$ around a lake and the rivers, as demonstrated by several authors (Jackson and Wong 1992, Jackson 1994, Sugita 1994, Punning and Koff 1997). The high concentration of pollen types in our samples can probably be considered a result of pollination of herbs, shrubs and trees of the hygrophilous vegetation, reflecting the local vegetation of the southwest margins of the Lagoa de Cima Lake and also of the Imbé and Urubu Rivers.

It was interesting to notice the presence of Podocarpus pollen grains in a sample from the southwest margin of the lake. Nowadays, this tree can be found only in the high altitudes of the Paraíba do Sul River basin (Carauta and Rocha 1988). The fluvial transport of pollen and spores supplies a better vision of the vegetation than the aerial one, as also demonstrated by Chmura et al. (1999). It includes high values of palynomorph frequency that may not be related to an anemophylous transport only. Pollen types of plants of zoophile pollination, as Bombax and Cedrela, fall down by gravity directly into the water or may come by the rivers from plants located far from the depositional site. However, the possibility of input of palynomorphs by air directly into the lake cannot be discarded, not only from the local vegetation but also from regional areas. The presence of these pollen types in the samples from the southwest margin of the lake indicates long distance dispersion, as well as a process of pollen capture by the Imbé River. These pollen types will be deposited preferentially nearby the inflow of the Imbé River into the lake.

Traverse (2007) suggested that a normal depositional pattern of pollen and spores in rivers is the arrangement of pollen assemblages in decreasing concentrations from the outlet. Pollen and spores of large to very large size showed preferential deposition in the southwest area of the lake in a decreasing gradient of concentration from the inflows, following the fluvial current towards the northeast margin of the lake. Small and very small sized pollen types and spores in high concentrations were deposited in samples 6 and 5 of the transect. This observation indicates that the decrease of depth in this locality constitutes a physical barrier to the SW-NE aquatic transport of these pollen grains, as also explained by Davis (1968).

The erosion of the Lake margins by torrent waters during rainy periods, mainly the ones of the Imbé River, led to a great input of pollen and spores in the lake sediments. A high percentage of degraded pollen and spores was seen mainly in the southwest surface samples, which is the entrance area of the Imbé and Urubu Rivers. Rich organic sediments of older adjacent stratigraphic layers, and formerly exposed to the air, may also be incorporated into the sediments, resulting in a strong representation of the vegetation nearby these inflows (mostly Pteridophytae, Poaceae, Cyperaceae and Piper).

The deposition of Chloroccocales algae was observed only at the deeper and calm water portions of the Lagoa de Cima Lake, which are better protected from the inflow currents. Bacillariophyceae were very abundant in all the surface samples, as Huszar and Esteves (1988) and Huszar and Silva (1992) pointed out. Esteves et al. (1984) considered the Lagoa de Cima Lake as oligothrophic, with low density of algae, but Huszar and Silva (1992), noted a high specific richness of algae in it, mostly during the rainfall periods. The most abundant species belonged to Desmidiaceae and Mougeotia cf. delicata. Despite zigospores of these algae have been observed in low frequency, we agree with Huszar and Silva (1992), regarding the high concentration values and richness of algae in our samples.

The palynological analysis of the surface samples from Lagoa do Campelo Lake showed a strong deposition of pollen grains from hydrophylous/swampy plants and less from "Restinga" arboreal/shrubs. Local plant species provided the dominant assemblages of herbaceous vegetation. The belt bordering vegetation of Lagoa do Campelo Lake was largely reflected by Typhaceae, Poaceae and Cyperaceae in the pollen spectra. Sample 1 showed the highest frequency of Typha. Sample 3 was the deepest one and located near a sand bank 

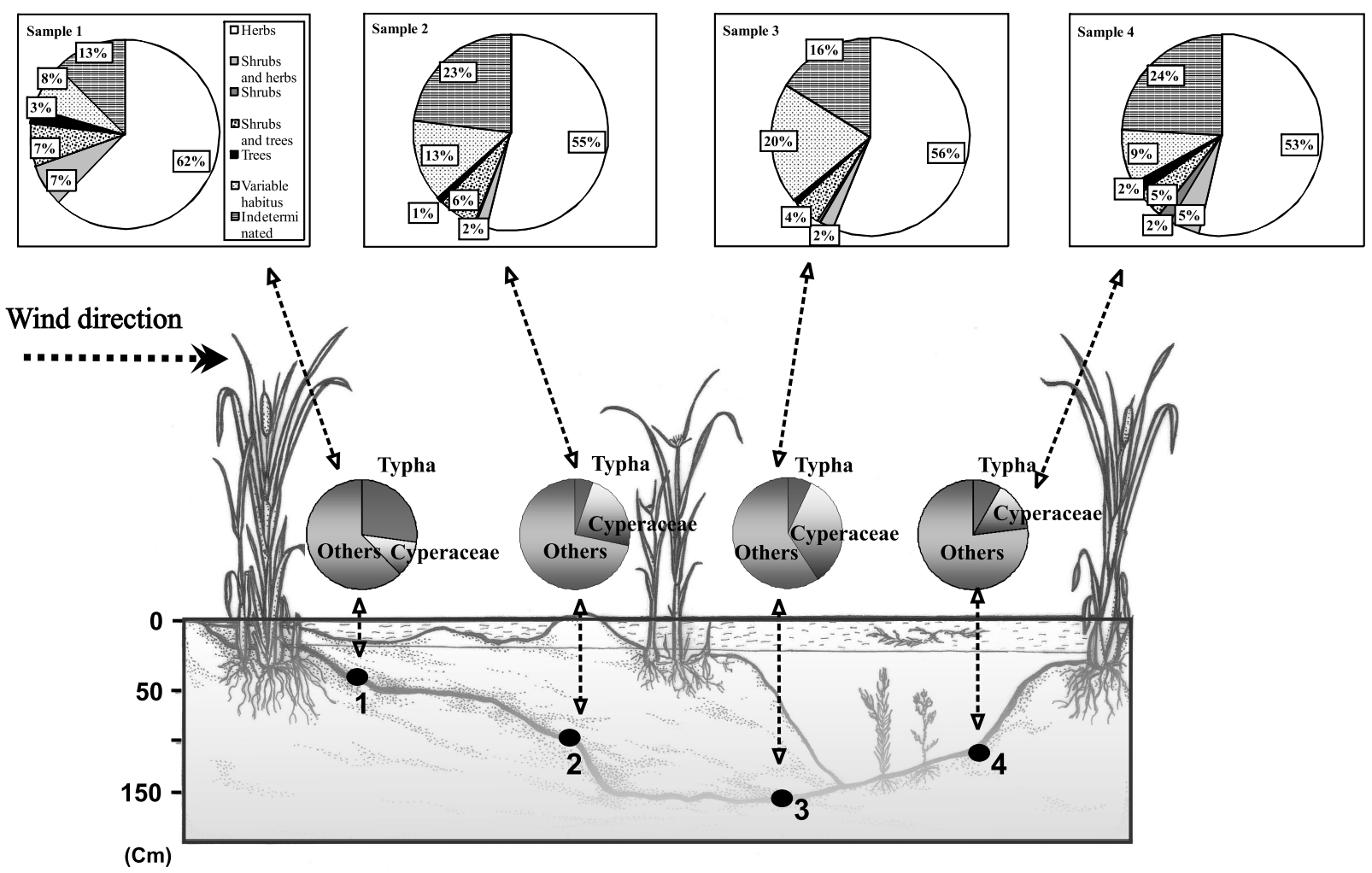

Fig. 5 - Surface samples from the Lagoa do Campelo Lake and frequencies of Typha, Cyperaceae and other pollen grains.

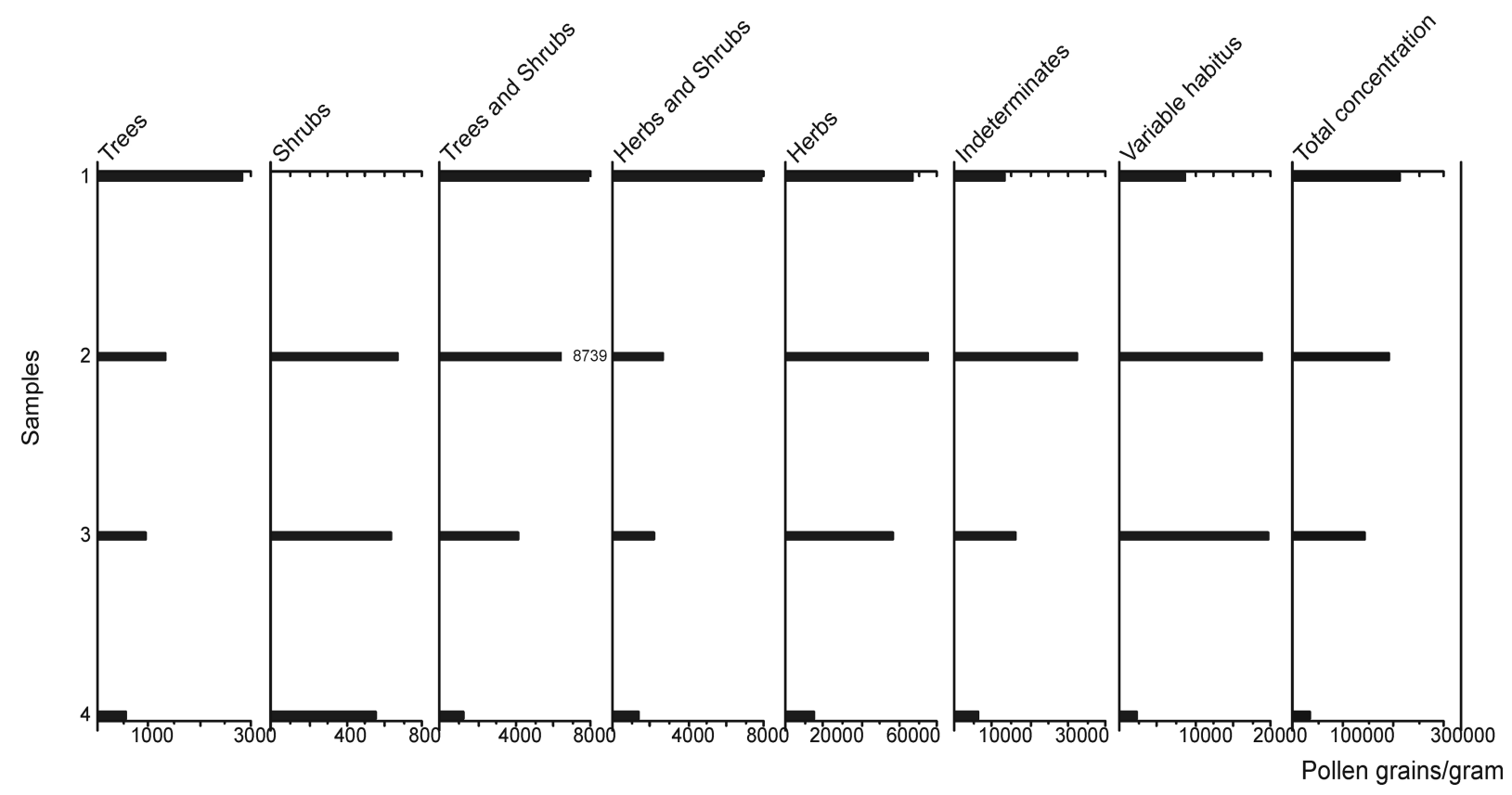

Fig. 6 - Total concentration of pollen grains according to the plant habitus, spores of Pteridophyta and algae, at the surface samples of the Lagoa do Campelo Lake. 
with Cyperaceae, which reflects the highest frequency of this pollen type in the sediment. Sample 4 showed the greatest percentual of regional pollen grains with damaged exine. The arboreal and shrub pollen types probably came from plants of a little forest fragment that is adjacent to the northeast border of the lake, comprising representatives of the "Restinga" forest (Assumpção and Nascimento 2000) and of the Seasonal Semideciduous forest (Silva and Nascimento 2001). Degraded pollen grains came from the nearby bogs and swampy areas that are frequently exposed to oxidation and microbial activity. Successive wetting and drying caused significant damages to palynomorphs and was rapid and severe (Campbell 1991, 1999). The west margin was the best depositional place of wind-pollinated arboreal pollen grains and was of less concentration of pollen grains. This pattern may be explained by the NE wind that caused turbulence of the lake's water that spread pollen grains laterally into other areas, before and after sinking down (reworked grains). Pollen grains probably suffered constant processes of ressuspension in this margin. The depositional processes of palynomorphs in the Lago do Campelo Lake are strongly influenced by the NE wind, by the bathymetry of the lake, and by the input of pollen grains and spores formerly deposited in swampy areas around the lake.

Lagoa de Cima and Lagoa do Campelo lake surface samples revealed a differentiate standard of deposition of palynomorphs, as well as surface sediments from the Lagoa Salgada Lake (Barth et al. 2001, Luz et al. 2005). This lake is also located in the northern region of Rio de Janeiro State, of at about 1,5 km from the seashore, near Cape São Tomé. It has no tributaries, lying in the coastal plain between the sand barriers (beach ridges) and the mouth of the delta of the Paraíba do Sul River, with a characteristic vegetation of the herbaceous "Restinga" nevertheless, this area has been disturbed by anthropogenic action since the eighteenth century. The palynologycal analysis made by Barth et al. (2001) showed a dry-open environment with high frequency of herbs, and very low representation of trees, shrubs, hydrophylous plants (Typha and Cyperaceae) and Pteridophyta. The distribution of palynomorphs in the surface sediments of this lake was mainly affected by the wind direction and also by the morphology of the lake (M.B.
Toledo, personal communication), similar to the conditions observed in the Lagoa do Campelo Lake.

\section{CONCLUSIONS}

Pollen grains occurring in samples obtained in the superficial sediments from a transect across the Lagoa de Cima Lake reflect the extant vegetation around the lake and along the Imbé and Urubu Rivers, with an expressive contribution of arboreal regional taxa, as well as an important contribution of hydrophylous/swampy plant species and ruderal plants from the wide-ranging pasturelands in this region. In the Lagoa de Cima Lake, the ressuspended sediments take a preferential direction of deposition caused by water currents that generate high pollen rates in less deeper and decentralized areas.

Pollen and spore preservation was sometimes bad in the superficial sediments of the Lagoa do Campelo Lake, means their exposition to the air during the partial drying of the lake and corrosion by microorganisms. The pollen spectra indicate a major performance of the local vegetation and the preferential deposition of regional pollen types at the southwest margin of the lake, reflecting the action of the NE wind.

Taking in account the obtained results, the dynamic of deposition was different in the areas of the two studied lakes. At Lagoa de Cima Lake, it reflects the response of the vegetation to the sea level, always presenting a strong grouped influence of regional and local forest, grassland and swampy vegetation. Nevertheless, the dynamic of deposition in the Lagoa do Campelo Lake is in innermost dependence of the water level of the Paraíba do Sul River. The high number of pollen types is attributed to the local plants. The results reveal new information regarding the richness, concentration and distribution of the palynomorphs in the studied lakes, representing the regional and local vegetation and assisting in the paleoecological studies in the region.

\section{ACKNOWLEDGMENTS}

To the Conselho Nacional de Desenvolvimento Científico e Tecnológico (CNPq) for a doctoral scholarship to the first autor and a fellowship to the second one. To the Fundação Carlos Chagas Filho de Amparo à Pesquisa do Estado do Rio de Janeiro (FAPERJ) and WWF (World 
Wild Foundation) for financial support. Thanks to Bruno Santos Penha for technical assistance and to Dr. Luciane Guimarães Coelho for collaboration with Tilia Graph computer program. The first author acknowledges the Brazilian "Conselho Nacional de Desenvolvimento Científico e Tecnológico" for the fellowship of "Produtividade em Pesquisa" (CNPq \#301220/2009-3).

\section{RESUMO}

A análise palinológica de grãos de pólen, esporos de Pteridophyta e algas depositados nos sedimentos superficiais da Lagoa de Cima e Lagoa do Campelo, norte do Rio de Janeiro, foi usada para a avaliação da variação espacial de deposição dos palinomorfos. Um total de 67 tipos polínicos foi identificado na Lagoa de Cima, com expressiva contribuição de taxons arbóreos regionais, plantas hidrófitas e ruderais de pastagens. O padrão deposicional dos palinomorfos está sujeito às vazões fluviais, à proximidade do local de sedimentação em relação à desembocadura dos rios Imbé e Urubu e à batimetria do leito da lagoa. As maiores concentrações de palinomorfos foram observadas em áreas descentralizadas e menos profundas, não interferindo a ação dos ventos NE. Já na Lagoa do Campelo foi identificado um total de 58 tipos polínicos, em sua maioria de grãos de pólen de hidrófitas, com área de maior concentração relacionada à borda nordeste. A borda sudoeste apresentou altas percentagens de pólen e esporos com a exina degradada e danos mecânicos, resultado da ação de correntes aquáticas impulsionadas pelo vento, confirmando ser a tendência deposicional dos palinomorfos danificados a mesma da direção dos ventos dominantes.

Palavras-chave: deposição de algas, município de Campos dos Goitacazes, palinologia, deposição polínica.

\section{REFERENCES}

AssumpÇÃo J AND NASCIMENTO MT. 2000. Estrutura e composição florística de 4 formações vegetais de Restinga no complexo lagunar Grussaí/Iquipari, São João da Barra, Rio de Janeiro, Brasil. Acta Bot Bras 14: 301-315.

Barth OM, Luz CFP, TOledo MB, Barros MA AND SILVA CG. 2001. Palynological data from Quaternary deposits of two lakes in the northern region of the state of Rio de Janeiro. In: Goodman DK And Clarke RT (Eds), Proceedings of the IX Palynological Congress, Houston, Texas, USA, 1996, American Association of Stratigraphic Palynologists Foundation, p. 443-450.
Bidegain P. 2002. Lagoas do Norte Fluminense - Perfil Ambiental. Rio de Janeiro: Semads, 148 p.

CAMPBell ID. 1991. Experimental mechanical destruction of pollen grains. Palynology 15: 29-33.

CAMPBELL ID. 1999. Quaternary pollen taphonomy; examples of differential redeposition and differential preservation. Palaeogeogr, Palaeoclimatol, Palaeoecol 149: 245256.

CARAUtA JPP AND Rocha ESF. 1988. Conservação da flora do trecho fluminense da bacia hidrográfica do rio Paraíba do Sul. Albertoa 11: 86-135.

Carauta JPP, Lima DF, Vianna MC, Ascenção MR AND LINS EAM. 1992. Vegetação da floresta da Cicuta, estado do Rio de Janeiro, observações preliminares. Albertoa 11: 101-124.

Chmura GL, Smirnov A And Campbell ID. 1999. Pollen transport through distributaries and depositional patterns in coastal waters. Palaeogeogr, Palaeoclimatol, Palaeoecol 149: 257-270.

DAVIS MB. 1968. Pollen grains in lake sediments: redeposition caused by seasonal water circulation. Science 162: 796-799.

Departamento de Recursos Minerais do Rio de JANEIRO (DRM). 1976. Fotografias aéreas do sobrevoo realizado pela Força Aérea Brasileira (FAB), litoral norte Fluminense. Escala; 1:20.000

Esteves FA, Ishit I And CAmargo AF. 1984. Pesquisas limnológicas em 14 lagoas do litoral do Estado do Rio de Janeiro, p. 443-454. In: LACERDA LD, ARAUJO DSD, CERqueira R AND TurCQ B (Eds), In: Restingas: ORIGEM, ESTRUTURA, PROCESSOS. Universidade Federal Fluminense, Niterói. RJ, Brasil.

FundaÇão Estadual de Engenharia do Meio AmbiENTE (FEEMA). 1993. Perfil ambiental do município de Campos, Rio de Janeiro, $146 \mathrm{p}$.

GRIMM EC. 1987. CONISS: a 77 program for stratigraphically constrained cluster analysis by the method of incremental sum of squares. Comput Geosci 2: 13-35.

Huszar VLM And Esteves FA. 1988. Considerações sobre o fitoplâncton de rede de 14 lagoas costeiras do Estado do Rio de Janeiro, Brasil. Acta Limnol Bras 2: 323-345.

Huszar V AND SILVA LHS. 1992. Comunidades fitoplanctônicas de quatro lagoas costeiras do norte do Estado do Rio de Janeiro, Brasil. Acta Limnol Bras 4: 291-314.

Instituto BRAsileiro de Geografia e Estatística. 1968. Carta topográfica do IBGE, escala 1:50.000, Folha São João da Barra. 
JACKSON ST. 1994. Pollen and spores in quaternary lake sediments as sensors of vegetation composition: theoretical models and empirical evidence, p. 253-286. In: TRAVERSE A (Ed), Sedimentation of organic particles. Cambridge University Press, Cambridge.

JACKSON ST AND WONG A. 1992. Using forest patchiness to determine pollen source areas of closed-canopy basins. ESA Bulletin 73: 221.

LuZ CFP AND BARTH OM. 2000. Palinomorfos indicadores de tipos de vegetação em sedimentos holocênicos da Lagoa de Cima, norte do estado do Rio de Janeiro, Brasil-Dicotyledoneae. Leandra 15: 11-34.

LUZ CFP AND BARTH OM. 2002. Palinomorfos indicadores de tipos de vegetação em sedimentos holocênicos da Lagoa de Cima, norte do estado do Rio de Janeiro, Brasil-Monocotyledoneae, Lycopodophyta, Pteridophyta e Bryophyta. Leandra 17: 7-22.

Luz CFP, Nogueira IS, BARTh OM AND Silva CG. 2002. Differential sedimentation of algae Chlorococcales (Scenedesmus, Coelastrum and Pediastrum) in Lagoa de Cima, Campos dos Goitacazes municipality (Rio de Janeiro, Brazil). Pesqui Geocienc 29: 65-75.

Luz CFP, BARTh OM AND Silva CG. 2005. Spatial distribution of palynomorphs in the surface sediments of the Lagoa do Campelo lake, north region of Rio de Janeiro state, Brazil. Acta Bot Bras 19: 741-752.

Martin L, Bittencourt ACSP, Flexor JM AND ViLAS-BOAS GS. 1984. Enregistrement de périodes de fortes et faibles énergies à l'embouchure d'un fleuve. Le cas du Paraíba do Sul (Brésil). Implications paléoclimatiques. Comptes Rendus - Academie des Sciences, Ser II 299: 661-664.

Martin L, Suguio K and Flexor JM. 1993. As flutuações do nível do mar durante o Quaternário Superior e a evolução geológica de "deltas" brasileiros. Boletim IG USP 15 (publ. especial), 186 p.

Martin L, Suguio K, Dominguez JML and Flexor JM. 1997. Geologia do Quaternário costeiro do litoral norte do Rio de Janeiro e do Espirito Santo. Publicação CPRM (Serviço Geológico do Brasil) \& FAPES (Texto explicativo, 2 folhas coloridas na escala do 1/250 000. Folha do Espírito Santo e Folha do Norte do Estado do Rio), $104 \mathrm{p}$.
Moreno MR, Nascimento MT And Kurtz BC. 2003. Estrutura e composição florística do estrato arbóreo em duas zonas altitudinais diferentes em mata Atlântica de encosta na região do Imbé, RJ. Acta Bot Bras 17: 371386.

PUNNING JM AND Koff T. 1997. The landscape factor in the formation of pollen records in lake sediments. J Paleolimnol 18: 33-44.

RADAmBRASil Projeto. 1983. Levantamento de recursos naturais, Geologia, Geomorfologia, Pedologia, Vegetação. Uso Potencial da Terra (Folhas SF 23/24 - RJ Vitória). Publicação do Ministério das Minas e Energia, v. 32 .

RizZini CM, AduAn RE, Jesus R And GARAY I. 1997. Floresta Pluvial de Tabuleiro, Linhares, ES, Brasil: sistemas primários e secundários. Leandra 12: 54-76.

Silva GC AND NAscimento MT. 2001. Fitossociologia de um remanescente de mata sobre tabuleiros do norte do estado do Rio de janeiro (mata do Carvão). Rev Bras Bot 24: $51-62$.

Soffiati Netto AA. 1985. A agonia das lagoas do Norte Fluminense. Cienc Cult 37: 1627-1638.

Soffiati Netto AA. 1991. Diagnóstico ambiental da região Norte-Noroeste fluminense. Rio de Janeiro, Relatório do Centro Norte Fluminense para a Conservação da Natureza, $28 \mathrm{p}$.

StOckMARR J. 1971. Tablets with spores used in absolute pollen analysis. Pollen et Spores 13: 615-621.

SugiTA S. 1994. Pollen representation of vegetation in Quaternary sediments: theory and method in patchy vegetation. J Ecol 82: 881-897.

Tolentino M, Esteves FA, Roland F And ThomaZ SM. 1986. Composição química do sedimento de 12 lagoas do litoral fluminense e sua utilização na tipologia destes ecossistemas. Acta Limnol Bras 1: 431-447.

Traverse A. 2007. Paleopalynology. $2^{\text {nd }}$ ed., Landman and Jones (Eds), $813 \mathrm{p}$.

Ybert JP, SAlgado-Labouriau ML, BARth OM, LorscheitTer ML, Barros MA, Chaves SAM, Luz CFP, Ribeiro MB, SCHEEL R AND VicENTINI KF. 1992. Sugestões para padronização da metodologia empregada em estudos palinológicos do Quaternário. Rev Inst Geol 13: 47-49. 